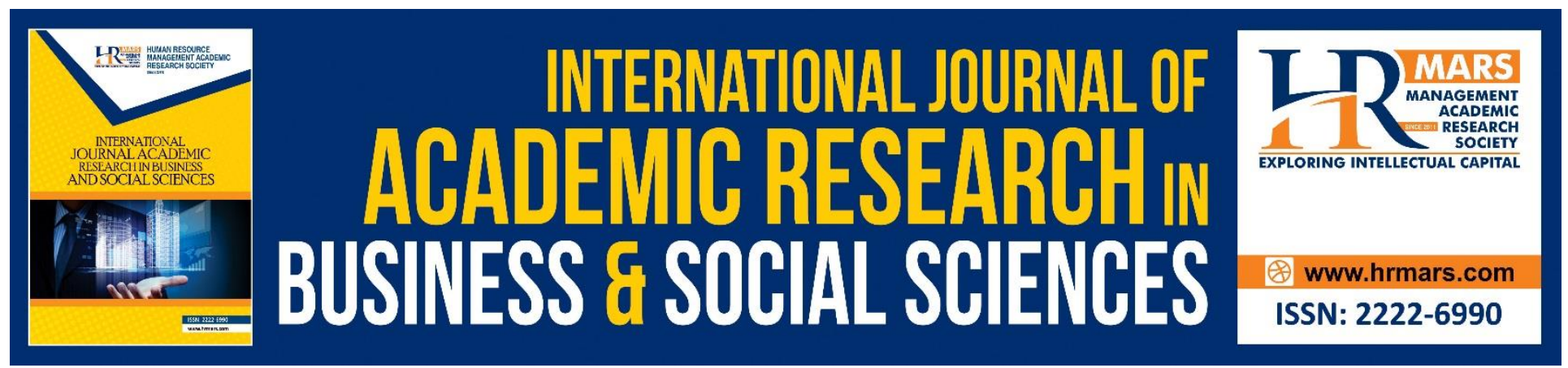

\title{
Entrepreneurship Readiness among Students of Technical and Vocational Education and Training (TVET) Institutions in Malaysia
}

\author{
Dzuhailmi Dahalan, Jeffrey Lawrence D’Silva, Ismi Arif Ismail, Nor Aini \\ Mohamed
}

To Link this Article: http://dx.doi.org/10.6007/IJARBSS/v10-i15/8241

DOI:10.6007/IJARBSS/v10-i15/8241

Received: 03 October 2020, Revised: 26 October 2020, Accepted: 19 November 2020

Published Online: 28 November 2020

In-Text Citation: (Dahalan et al., 2020)

To Cite this Article: Dahalan, D., D'Silva, J. L., Ismail, I. A., \& Mohamed, N. A. (2020). Entrepreneurship Readiness among Students of Technical and Vocational Education and Training (TVET) Institutions in Malaysia. International Journal of Academic Research in Business and Social Sciences, 10(15), 164-175.

Copyright: (c) 2020 The Author(s)

Published by Human Resource Management Academic Research Society (www.hrmars.com)

This article is published under the Creative Commons Attribution (CC BY 4.0) license. Anyone may reproduce, distribute, translate and create derivative works of this article (for both commercial and non-commercial purposes), subject to full attribution to the original publication and authors. The full terms of this license may be seen at: http://creativecommons.org/licences/by/4.0/legalcode

Special Issue: Youth and Community Wellbeing: Issues, Challenges and Opportunities for Empowerment V1, 2020, Pg. 164 - 175

Full Terms \& Conditions of access and use can be found at http://hrmars.com/index.php/pages/detail/publication-ethics 


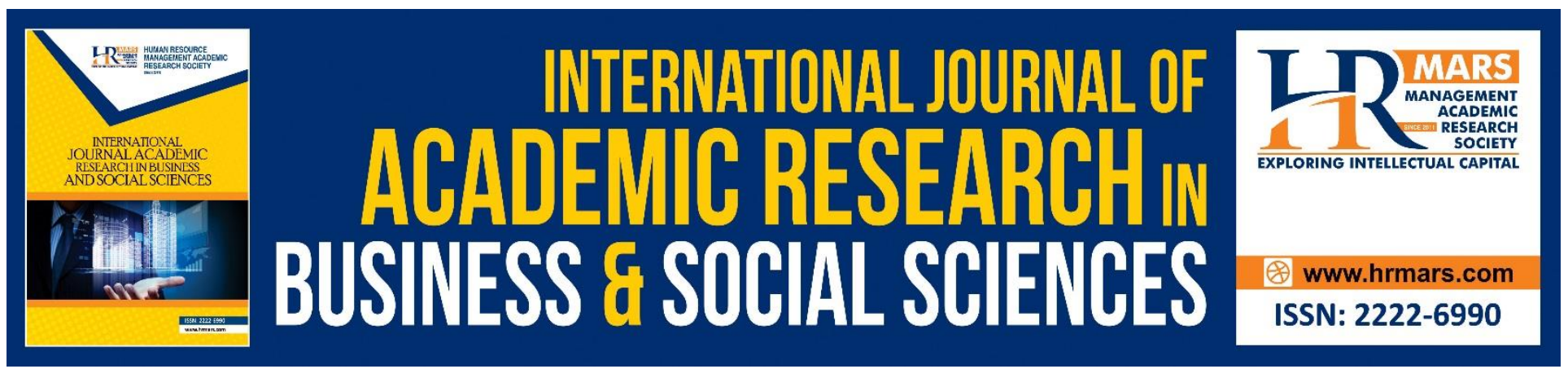

\title{
Entrepreneurship Readiness among Students of Technical and Vocational Education and Training (TVET) Institutions in Malaysia
}

\author{
Dzuhailmi Dahalan, Jeffrey Lawrence D'Silva \\ Institute for Social Science Studies, Universiti Putra Malaysia, 43400 Serdang, Selangor, Malaysia \\ Email: dzuhailmi@gmail.com, jld@upm.edu.my
}

Ismi Arif Ismail

Institute for Social Science Studies, Universiti Putra Malaysia, 43400 Serdang, Selangor, Malaysia

Professional Development \& Continuing Education's Department, Universiti Putra Malaysia

Email: ismi@upm.edu.my

Nor Aini Mohamed

Institute for Social Science Studies, Universiti Putra Malaysia, 43400 Serdang, Selangor, Malaysia

Email:nm_aini@upm.edu.my

\begin{abstract}
This paper examines the readiness for entrepreneurship among the students of Technical and Vocational Education and Training (TVET). The findings are from a quantitative study which involves 1000 students from eight selected public TVET institutions in Peninsular Malaysia. Overall, the study found that respondents had a moderate level of readiness to be involved in entrepreneurship. Moreover, there is no significant difference of entrepreneurship readiness between the respondents at the certificate level and diploma level. However, the study shows that there is a significant difference between the entrepreneurial readiness's of respondents that have family/parents who have entrepreneurial background compared to those who have parents with no entrepreneurial background. In addition, the study also reveals that there is also a significant difference in entrepreneurial readiness between the respondents who were engaged in entrepreneurial activities and those who were not engaged at all while studying. Studies have shown positively that the readiness of students at TVET institutions for entrepreneurship has the potential to be improved if significant factors that can encourage students' readiness towards continuous entrepreneurship can be systematically applied in the programme of study. Concurrently, this study also suggests that the
\end{abstract}


INTERNATIONAL JOURNAL OF ACADEMIC RESEARCH IN BUSINESS AND SOCIAL SCIENCES

Vol. 10, No. 15, Youth and Community Wellbeing: Issues, Challenges and Opportunities for Empowerment V1. 2020, E-ISSN: 2222-6990 @) 2020 HRMARS

opportunity to conduct entrepreneurial activities should be broadly open to TVET students based on the appropriate guidelines that may be developed according to the programme of study.

Keywords: Readiness, TVET Students, Entrepreneurship, Skill, Training Development.

\section{Introduction}

The field of entrepreneurship is seen as the best mechanism for reducing unemployment among youths in Malaysia, especially among the higher education institutions (HEls). Entrepreneurs are seen to have the potential to generate the country's economic growth by acting as a job creator. It is generally known that the country's youths especially $\mathrm{HEl}$ graduates are facing serious challenges in placing themselves in their choice of careers. This is due to the growing expectations of employers and job challenges, where graduates are not only assessed from the perspective of academic qualifications, but are also viewed in terms of capabilities and other value added skills (Dzuhailmi, et al., 2018). The growth of employment structure in a slow-paced country that is unable to accommodate the growing number of graduates (Nooriah, Zakiah \& Norain, 2013) is seen to continuously put pressure in the existing labour market. The problem of graduates depending only on job market opportunities is not a new issue in Malaysia (Masidi, 2014). Hence, an integrated collaboration and support from all parties, especially towards the country's higher education sector, should be worked out effectively to produce as many job creators in the labour market as possible (Dzuhailmi, et al., 2018).

The involvement of the population in the entrepreneur field will generate the country's economic growth, create employment opportunities, and thereby reduce the unemployment rate (Department of Statistics Malaysia, 2009). Furthermore, efforts to strengthen entrepreneurship either towards entrepreneurial mind-set or the inclination to become entrepreneurs through education have been proven to increase graduates' marketability, solve unemployment issues among youth, increase the socio-economic level of the society and reduce the gap between the rich and poor groups (Ministry of Higher Education, 2016). Recognising this fact, the government through the Ministry of Higher Education (MoHE), has introduced the Higher Education Entrepreneurship Development Policy on April 13, 2010 which aims to promote and strengthen entrepreneurship development and education in Higher Education Institutions (HEIs) in a more organised and holistic way. The elements of this policy are as follows:

1. Producing quality human beings who have entrepreneurial mind-set, attributes and values;

2. Increasing the number of $\mathrm{HEI}$ graduates venturing into entrepreneurship as a career; and

3. Developing academicians, researchers and administrators who are capable and have entrepreneurial minds.

To ensure that these objectives are achieved, MoHE has developed a comprehensive and pragmatic plan which is the Entrepreneurial Strategic Plan for Higher Education Institutions for the period of 2013 to 2015 (Ministry of Higher Education, 2016). Currently, the government is seen as permanently committed in implementing the initiatives for the job creator framework that has been drafted under HEl Entrepreneurship Action Plan 2016-2020. This plan is introduced in line with the aspiration of the Malaysia Education Blueprint 2015-2025 (MEB) to inculcate the entrepreneurial mind-set into the entire higher education system and create an education system capable of 
INTERNATIONAL JOURNAL OF ACADEMIC RESEARCH IN BUSINESS AND SOCIAL SCIENCES

Vol. 10, No. 15, Youth and Community Wellbeing: Issues, Challenges and Opportunities for Empowerment V1. 2020, E-ISSN: 2222-6990 @) 2020 HRMARS

producing graduates with entrepreneur characteristics and become job creators, while ensuring the financial sustainability the country's HEl.

Based on this statement, all parties need to realise that the education and entrepreneurship sector are two of the key aspects of the current government's interest in making Malaysia a highly developed and inclusive high-income nation. Furthermore, the application of entrepreneurial culture and values, especially through the higher education sector, is emphasised so that the learning process will enable students to become more creative, innovative and viable as well as able to generate innovation, job opportunities and more robust economic growth in the future.

\section{Literature Review}

The previous studies found that the HEl students had low and medium career readiness level (Hughes, 2011; Mansor \& Tan, 2009; Maznizam \& Abdullah, 2013). This is a challenge to the HEl to provides their students with skills that suit their interests, abilities and talents, decision-making skills and information seeking, apart from interpersonal relationships (Suradi, 1996), where all these are important elements that can measure the readiness of students in their career planning.

Career readiness is an individual's ability to make a suitable career choice taking into account the factors of affecting the career development such as family, organization, social and economic (Sampson et al., 2013; Reardon et al., 2012). Lombardi et al., (2012) and Conley (2012) has defined career readiness as knowledge, skills and learning strategies in the context of the beginning of the study or getting training in career paths including willing to work, work-in-training, basic expectations related to the behaviour at work and specific knowledge.

According to Sampson et al., (2013), low career readiness is influenced by several factors such as personal characteristics and circumstances, knowledge of self, choice and decision making, and experience with career intervention. The ability to make career decisions is related to career mindset which involves feelings, thoughts, attitudes, and expectations of trust (Bullock-Yowell et al., 2013).

Negative of career mind-set is a non-working individual thoughts and this will affect the career decision making process and the problem solving ability. Individuals who had a low career decisionmaking efficacy are tends to have a negative career mind-set. Therefore, by identifying the negative career mind-set, it's help in designing an appropriate intervention strategy for an individual (Andrews et al., 2014; Sidiropoulou-Dimakakou et al., 2012; Thrift et al., 2012).

The 10th Malaysia Plan (10MP) for the period 2011-2015 has shown dramatic planning in the country's Technical and Vocational Education (TVET) system. This is in line with the government's strategy to mainstream TVET in order to provide an alternative to the society, especially youth, and to highlight their full potential in accordance with their own talents and inclinations. The statistic up to 2010 show that the number of technical students produced is 28,171 . Meanwhile, the enrolment of students in public technical and vocational training institutions increased by 1.5 per cent per annum following the construction of 10 skills training institutions and the upgrading of 16 existing institutions (Government of Malaysia, 2010).

Reciting the "Statement of the former Media Minister of Higher Education" on HEI Graduate Marketability 2016, TVET graduates have shown a steady increase in marketability for the year 2016 where the rate of graduates' marketability for Malaysian technical universities is at $87.1 \%$ followed by Polytechnic (88.6\%) and Community College (97.2\%). While this scenario looks positive from one 
INTERNATIONAL JOURNAL OF ACADEMIC RESEARCH IN BUSINESS AND SOCIAL SCIENCES

Vol. 10, No. 15, Youth and Community Wellbeing: Issues, Challenges and Opportunities for Empowerment V1. 2020, E-ISSN: 2222-6990 @) 2020 HRMARS

perspective, the fact is that this data continues to contribute to Malaysia's low achievement in terms of entrepreneurial intentions (UNIRAZAK, 2015) especially for TVET graduates involved in this context. Based on the Ministry's records, the number of HEI graduates who ventured into entrepreneurship soon after completing their studies is still very small, which is about $2 \%$ of the total number of graduates each year (Ministry of Higher Education, 2016). This data is in line with the Global Entrepreneurship Monitor (GEM) 2014 report which found only 50.37\% of Malaysians see entrepreneurship as a good career option. Furthermore, current trends suggest that Malaysians are more likely to engage in entrepreneurial activities because of opportunity-driven opportunities rather than necessity-driven (GEM, 2014).

According to the Higher Education Institution (HEI) Entrepreneurship Action Plan 2016-2020, the government's objective is that by the year 2020, $100 \%$ of HEl students will be exposed to entrepreneurship values and attributes under the Holistic and Integrated Curriculum Development Strategy through the Initiative: Implementing High Impact Education Practice (HIEP) by applying entrepreneurial elements across the curriculum and field of study. In addition, through the Initiative: Implementing Job Creator Framework, which is located under the Learning Support System Strengthening Strategy, the government's aim is for $5 \%$ of HEI graduates to be self-employed or opt for entrepreneurship as a career choice by 2020.

The targeted participation of $5 \%$ from the number of $\mathrm{HEI}$ students engaged in entrepreneurship is across the field of study and inclusive of TVET. This is because the HEI Entrepreneurship Action Plan 2016-2020 applies to all 20 public universities including the Polytechnic Education Department and the Community College Education Department. Therefore, this paper aims to examine the entrepreneurial readiness of TVET students in terms of producing a group of job creators.

Eriniwati (2014) in her study on the factors that actuate the inclination of vocational college students towards entrepreneurship discovers that factors such as skills, attitudes and educational backgrounds has a high influence on the students' inclination while family background factor only has moderate level of influence on the students' inclination. Her research sample consists of 150 third semester students in three vocational colleges namely Puteri Vocational College, Chenor Vocational College and Temerloh Vocational College. In addition, Hassan (2007) found that motivation, attitude and skill factors were important factors that motivated graduates from Universiti Teknologi Malaysia to venture into entrepreneurship. His research involved 53 alumni of the university who are involved in entrepreneurship. However, the background of the programme of study undertaken by the graduates is unknown.

A study by Azilahwati et al., (2015) among students of Jasin Community College reveals that the students showed a high interest in entrepreneurship if given the opportunity to start a business along with the necessary resources. Their study also found that factors such as supporting the family and offering services to the community are strong impetuses for students to venture into entrepreneurship. Their study involved all 32 final semester students pursuing Accounting Certificate, Architectural Design Certificate Certificate, Computer System and Support Certificate, and Creative Multimedia Certificate (Advertising) at the Jasin Community College

Yusrizal (2012) finds that motivation and environment factors influence entrepreneurship inclination at a moderate level. Consequently, there is a positive significant relationship between the exposure to entrepreneurship courses during study, entrepreneurship experience and the type of 
INTERNATIONAL JOURNAL OF ACADEMIC RESEARCH IN BUSINESS AND SOCIAL SCIENCES

Vol. 10, No. 15, Youth and Community Wellbeing: Issues, Challenges and Opportunities for Empowerment V1. 2020, E-ISSN: 2222-6990 @) 2020 HRMARS

courses taken on the entrepreneurial inclination of students. He found that vocational education students as a whole have an inclination towards entrepreneurship. His research involved the final year students of vocational skills community college in the southern region of Peninsular Malaysia involving students of Bandar Penawar Community College and Pasir Gudang Community College.

A study by Adam et al., (2011) shows that all students showed a high level of inclination towards entrepreneurship. The study also reveals that students are interested in starting a business if given the opportunity and the necessary resources. This study found that the students also had a great source of motivation towards entrepreneurship. They also found that most of the programmes implemented were able to cultivate entrepreneurship among students. This study involved 32 final year students of Jasin Community College and examined the level of the students' inclination towards entrepreneurship by identifying their interests, sources of motivation and consolidation of the student entrepreneurship culture.

In short, the studies on the readiness of TVET students for entrepreneurship in Malaysia are seen to be more focused on factors that influence the student's inclination towards entrepreneurship, while simultaneously measuring their level of readiness.

\section{Methodology}

This study employed quantitative methods. The data were collected using questionnaires, selfadministered by respondents. Simple random sampling was used which involved 1000 respondents comprising of students from community colleges and selected polytechnics under the Ministry of Higher Education Malaysia. This nation-wide study involves four community colleges and four selected polytechnics in Peninsular Malaysia in the north, south, east and central zones. The field surveys took a month and were carried out in March 2018. The data were analyzed using descriptive and inferential statistics. Mean score and standard deviation are used to measure the readiness of students for entrepreneurship while an independent t-test is used to see whether there is a significant difference in the readiness of students to be involved in entrepreneurship based on several selected demographic variables.

\section{Results and Discussion \\ Profile of Respondents}

Table 1 summarises the demographic profiles of the selected respondents. About $54.8 \%$ involved in this study were male respondents while $45.2 \%$ are female respondents. The percentage of respondents currently studying at the diploma level is $52.2 \%$ while the rest $(47.8 \%)$ are studying at certificate level. Majority of the respondents (52.2\%) stated that they have never attended any entrepreneurial course. However, this percentage is not significantly higher than the percentage of respondents who have attended entrepreneurial courses, which is $47.8 \%$. The respondents were asked whether they are currently involved in any entrepreneurial activities, and $54.9 \%$ of them respond negatively while $45.1 \%$ of them gave an affirmative response. The opportunity to increase income can be seen as the most prominent reason (30.5\%) for the respondents to be engaged in entrepreneurial activities. This is followed by occupying free time $(21.8 \%)$, covering educational expenses (20.3\%), hobby/merely interest (17.6\%), family/teacher/friend encouragement (15.8\%) and others $(2.4 \%)$ with the reasons to ease the family burden as well as the requirement of entrepreneurial subjects in their current learning institution. The respondents were also asked if their 
INTERNATIONAL JOURNAL OF ACADEMIC RESEARCH IN BUSINESS AND SOCIAL SCIENCES

Vol. 10, No. 15, Youth and Community Wellbeing: Issues, Challenges and Opportunities for Empowerment V1. 2020, E-ISSN: 2222-6990 @ 2020 HRMARS

family/parents are involved in any entrepreneurial activities. Data shows that $61.4 \%$ of them responded no while the rest (38.6\%) responded affirmatively.

Table 1: The Demographic Profile of Respondents ( $n=1000)$

\begin{tabular}{lc}
\hline Background & Percentage \\
\hline Gender & \\
Male & 54.8 \\
Female & 45.2 \\
Level of education & \\
Certificate & 47.8 \\
Diploma & 52.2 \\
Attended entrepreneurial course & \\
Yes & 47.8 \\
No & 52.2 \\
Currently involved in entrepreneurial activities & \\
Yes & 45.1 \\
No & 54.9 \\
Hobby/merely interest & 17.6 \\
Occupying free time & 21.8 \\
Covering educational expenses & 20.3 \\
Opportunity to gain income & 30.5 \\
Family/teacher/friend encouragement & 15.8 \\
Others & 2.4 \\
Yes & \\
No & 38.6 \\
Family/parents involving in entrepreneurial activities & 61.4 \\
\hline
\end{tabular}

\section{Entrepreneurship Readiness}

A 5-point Likert scale, (5) Strongly agree to (1) Strongly disagree, was used to measure the entrepreneurship readiness of the respondents. Furthermore, their level of readiness is determined by calculating the total amount of the mean constructs of measurement and divided by the number of items in readiness of choosing entrepreneurship as career to generate the overall mean. In general, the study reveals that the respondents have a moderate level of entrepreneurship readiness [M = $3.61, \mathrm{SP}=.730$ ]. Table 2 shows the level of entrepreneurship readiness of respondents based on the overall findings of the measurement constructs.

Table 2: The Level of Entrepreneurship Readiness of Respondents ( $n=1000)$

\begin{tabular}{lcccc}
\hline Level & Amount & Percentage & Mean & SD \\
\hline & & & 3.61 & .730 \\
Low (1.00-2.33) & 43 & 4.3 & & \\
Moderate (2.34-3.66) & 483 & 48.3 & & \\
High (3.67-5.00) & 474 & 47.4 & & \\
\hline
\end{tabular}


INTERNATIONAL JOURNAL OF ACADEMIC RESEARCH IN BUSINESS AND SOCIAL SCIENCES

Vol. 10, No. 15, Youth and Community Wellbeing: Issues, Challenges and Opportunities for Empowerment V1. 2020, E-ISSN: 2222-6990 @ 2020 HRMARS

Table 3 shows the descriptive distribution of each item that measures the entrepreneurship readiness of the respondents. The study reveals that there are four items that showed higher mean score related to the respondents' entrepreneurship readiness. The highest score [M=4.10] is shown for the item "To me, being self-employed is more profitable than earning a wage". This is followed by the item "Someday, I will be a successful entrepreneur", "I am more inclined to work for myself rather than work for others" and "I'm willing to take on whatever challenges to become an entrepreneur in the future" with a min score [M = 3.77]. Meanwhile, the remaining six items show a mean score of readiness at a moderate level.

Table 3: Mean distribution and standard deviation of items on the entrepreneurship readiness of respondents $(n=1000)$

\begin{tabular}{|c|c|c|c|}
\hline No. & Item & Mean & SP \\
\hline 1. & Someday, I will be a successful entrepreneur & 3.77 & .959 \\
\hline 2. & I will try my best to venture into entrepreneurship & 3.65 & .958 \\
\hline 3. & $\begin{array}{l}\text { I am more inclined to work for myself rather than work for } \\
\text { others }\end{array}$ & 3.77 & 1.030 \\
\hline 4. & $\begin{array}{l}\text { I am willing to explore the intricacies of business to achieve } \\
\text { the aspiration of becoming an entrepreneur }\end{array}$ & 3.60 & .936 \\
\hline 5. & $\begin{array}{l}\text { To me, being self-employed is more profitable than earning } \\
\text { a wage }\end{array}$ & 4.10 & .921 \\
\hline 6. & $\begin{array}{l}\text { I am willing to take on whatever challenges to become a } \\
\text { entrepreneur in the future }\end{array}$ & 3.77 & .904 \\
\hline 7. & $\begin{array}{l}\text { The passion to become an entrepreneur never faded within } \\
\text { me }\end{array}$ & 3.51 & .940 \\
\hline 8. & $\begin{array}{l}\text { Currently, I am participating in entrepreneurial courses on } \\
\text { my own willingness }\end{array}$ & 3.26 & 1.042 \\
\hline 9. & $\begin{array}{l}\text { I do not expect anyone to provide a job for me when I } \\
\text { complete my studies }\end{array}$ & 3.14 & 1.098 \\
\hline 10. & $\begin{array}{l}\text { I am researching a few business plans to venture into after I } \\
\text { complete my studies }\end{array}$ & 3.49 & .978 \\
\hline
\end{tabular}

An independent t-test was used to see if there were significant differences in the entrepreneurship readiness between the respondents at the certificate level and those at diploma level. The analysis found that there was no significant difference in the entrepreneurship readiness between the respondents at the certificate level $[\mathrm{M}=3.58, \mathrm{SP}=.712]$ and those at diploma level [M $=3.63, \mathrm{SP}=.746 ; \mathrm{t}(1000)=-.987 ; \mathrm{p}=.324 \mathrm{]}$. However, the analysis shows that there was a significant difference in entrepreneurship readiness between the respondents whose family/parents own businesses $[M=3.77, \mathrm{SP}=.693]$ and the respondents whose family/parents do not own any businesses $[M=3.50, S P=.734 ; t(1000)=5.710 ; p=.000]$. In other words, respondents who have family/parents with a background in business have higher entrepreneurship readiness than respondents who have family / parents without a background in business.

The analysis also present a significant difference in the entrepreneurship readiness between respondents involved with entrepreneurial activities $[\mathrm{M}=3.81, \mathrm{SP}=.675]$ and respondents who were 
INTERNATIONAL JOURNAL OF ACADEMIC RESEARCH IN BUSINESS AND SOCIAL SCIENCES

Vol. 10, No. 15, Youth and Community Wellbeing: Issues, Challenges and Opportunities for Empowerment V1. 2020, E-ISSN: 2222-6990 @) 2020 HRMARS

not involved with any entrepreneurial activity $[M=3.44, S P=.730 ; t(1000)=8.356 ; p=.000]$ where respondents involved with entrepreneurial activities during their studies have a higher level of readiness for entrepreneurship than respondents who are not involved with any entrepreneurial activity. Table 4 summarises the distribution of readiness for entrepreneurship based on the mentioned profiles.

Table 4: The difference in readiness for entrepreneurship based on selected profiles $(n=1000)$

\begin{tabular}{|c|c|c|c|c|c|c|}
\hline Profile & & $n$ & Mean & SP & $t$ & $p$ \\
\hline \multirow[t]{3}{*}{ Level of education } & & & & & -.987 & .324 \\
\hline & Certificate & 478 & 3.58 & .712 & & \\
\hline & Diploma & 522 & 3.63 & .746 & & \\
\hline \multirow[t]{3}{*}{ Family / parents } & & & & & 5.710 & .000 \\
\hline & In business & 386 & 3.77 & .693 & & \\
\hline & Not in business & 614 & 3.50 & .734 & & \\
\hline \multirow[t]{3}{*}{ Involved in business } & & & & & 8.356 & .000 \\
\hline & Yes & 451 & 3.81 & .675 & & \\
\hline & No & 549 & 3.44 & .730 & & \\
\hline
\end{tabular}

The above findings show that the background profile of having a family/parents who run businesses as well as the respondents' involvement in entrepreneurial activities while studying has significant relevance towards increasing the entrepreneurship readiness of the respondents. The findings relate the close relationship between the factors of family/parent's background and the readiness for entrepreneurship in this study are seen in parallel with some previous studies. Buerah et al., (2011) emphasises that role models are linked to individual entrepreneurship intentions, where early exposure and family involvement in entrepreneurship influence the inclination of children to become entrepreneurs. A study by Zaidatol and Hisyamuddin (2009) on form four school students in the state of Selangor also reveals that respondents made their parents as a role model for selfemployment. Similar findings are shown in a study by Eriniwati (2014) where she finds that family background factors influence the inclination of students to venture into entrepreneurship at a moderate level. Meanwhile, an entrepreneurship career study by Norashidah et al., (2009) also discovers that almost all respondents that were interviewed had family with business backgrounds.

Recent studies also show respondents who conducted business activities during their studies have a higher entrepreneurship readiness than those who did not conduct any business activities. In addition, a study by Mustafa et al., (2013) on final year students at one of the MARA Professional Colleges recommends that students be given the opportunity to apply entrepreneurship skills in their learning institution. This is because their research found that the motivation factor is one of the factors that influence the students' inclination to become entrepreneurs.

Meanwhile, the current study revealed that the level of study profile as the sole factor did not have any impact on increasing the respondents' readiness for entrepreneurship. This is because the study shows that there is no significant difference between the respondents at the certificate or diploma level in terms of spurring the readiness of respondents. There are other critical support 
INTERNATIONAL JOURNAL OF ACADEMIC RESEARCH IN BUSINESS AND SOCIAL SCIENCES

Vol. 10, No. 15, Youth and Community Wellbeing: Issues, Challenges and Opportunities for Empowerment V1. 2020, E-ISSN: 2222-6990 @) 2020 HRMARS

factors that need to be applied to the students in order to prepare them for entrepreneurship. Van Gelderen (2007) states that entrepreneurial skills are important in the entrepreneurial world. In fact, entrepreneurial skills are an integral part of soft skills. Moreover, soft skills include generic aspects that include communication skills, critical thinking and problem solving, teamwork skills, continuous learning and information management, entrepreneurial skills, morals and professional ethics as well as leadership skills (Ministry of Higher Education, 2006). A study by Norashidah et al., (2009) that explores the concept of entrepreneurship career readiness on six Small and Medium Enterprise (SME) entrepreneurs found that the respondents possess entrepreneurial skills such capability in their respective fields, management skills in business and resources as well as the ability to identify opportunities in their environment, generate creative and innovative ideas when facing competition.

\section{Conclusion}

The readiness for entrepreneurship among the students from selected TVET institutions in this study is seen to have the potential to be improved by all parties in order to produce as much job creators as possible. This will also reduce the dependency on existing public and private sectors in providing employment opportunities to $\mathrm{HEI}$ graduates. MoHE's record in 2016 shows that the number of $\mathrm{HEI}$ graduates who became involved in entrepreneurship after graduating is still very small which is around $2 \%$ of the total number of graduates each year. At the same time, the 10MP for the period of 2011-2015 has shown dramatic planning in the Technical and Vocational Education and Training (TVET) system in line with the government's strategy to make TVET mainstream in order to provide an alternative to the community, especially youth, and to highlight their full potential based on their talents and self-inclinations. Therefore, some of the important factors that influence the readiness of TVET students for entrepreneurship as discussed in this paper need to be thoroughly refined and applied in the programme of study at this institution, especially if the aim of creating more job creators becomes an important agenda for the government.

\section{References}

Adam, A., Abdul Razak, S., \& Abu Bakar, M. H. (2011). The tendency of final semester student at Jasin Community College towards entrepreneurship. Education Mini Seminar Jasin College Community.

Andrews, L. M., Bullock-Yowell, E., Dahlen, E. R., \& Nicholson, B. C. (2014). Can perfectionism affect career development? Exploring career thoughts and self-efficacy. Journal of Counseling \& Development, 92(3), 270-279. doi:10.1002/j.1556- 6676.2014.00155.x.

Bullock-Yowell, E., Chason, A. K., Sampson, J. P., Lenz, J. G., \& Reardon, R. C. (2013). Relationships among career thoughts, career interests, and career decision state. The Canadian Journal of Career Development/Revue Canadienne de Développement de Carrière, 12(1), 39-47.

Conley, D. T. (2012). A complete definition of college and career readiness. Eugene, OR: Educational Policy Improvement Center.

Department of Statistics Malaysia. (2009). Special broadcast of entrepreneur labour investigation in Malaysia: Series 1, No. 1/2009. 
INTERNATIONAL JOURNAL OF ACADEMIC RESEARCH IN BUSINESS AND SOCIAL SCIENCES

Vol. 10, No. 15, Youth and Community Wellbeing: Issues, Challenges and Opportunities for Empowerment V1. 2020, E-ISSN: 2222-6990 @) 2020 HRMARS

Dahalan, D., D’Silva, J. L., Ismail, I. A., \& Mohamed, N. A. (2018). Entrepreneurial mindset among students of technical and vocational education training (TVET) institutions in Malaysia. The Journal of Social Sciences Research, 4(11), 2413 - 6670.

Gelderen, V. M. (2007). Research based yet action oriented: Developing individual level enterprising competencies. Paper presented at $17^{\text {th }}$ Global Conference Internationalizing Entrepreneurship

Global Entrepreneurship Monitor (GEM). (2014). Global Entrepreneurship Monitor 2014 Global Report.

Government of Malaysia. (2010). The $10^{\text {th }}$ Malaysia Plan 2011-2015. Economic Planning Unit, Putrajaya.

Hashim, N., Othman, N., \& Buang, N. (2009). Entrepreneurship Readiness Concept based on the Small and Medium Industry (IKS) Entrepreneur Case Study in Malaysia. Jurnal Pendidikan Malaysia, 34(1), 187-203.

Hughes, C. (2011). The influence of self-concept, parenting style and individualism-collectivism on career maturity in Australia and Thailand. International Journal for Educational and Vocational Guidance, 11(3), 197-210.

Lombardi, A. R., Conley, D. T., Seburn, M. A., \& Downs, A. M. (2012). College and career readiness assessment: Validation of the key cognitive strategies framework. Assessment for Effective Intervention, 38(3), 163-171. doi:10.1177/1534508412448668.

Manjun, M. (2014). Dependency attitude causing the graduate failure. Utusan Malaysia, January 29, 2014.

Mansor, A. T., \& Tan, K. A. (2009). Influence of gender on career readiness among Malaysian undergraduates. Australian Journal of Career Development, 18, 33 - 44 . doi:10.1177/103841620901800206.

Mansor, M., \& Rashid, M. A. (2013). Career indecision: A cross-sectional survey among students of National Youth Skills Traning Institutes. Middle East Journal of Scientific Research, 17(8): 1073-107. doi:10.5829/idosi.mejsr.2013.17.08.12297.

Miaat, E. A. (2014). The factors that drive the tendency of vocational college student towards entrepreneurship. Master Thesis Dissertation, Universiti Tun Hussein Onn Malaysia.

Ministry of Higher Education. (2006). Soft Skill Development Module for Higher Education Institute. Universiti Putra Malaysia.

Ministry of Higher Education. (2016). Media Statement by Minister of Higher Education: Employability of Higher Education Institute Graduates in Malaysia increased 2016.

Ministry of Higher Education. (2016). Higher Education Institute Entrepreneurship Action Plan 2016 2020. Putrajaya, Ministry of Higher Education.

Mustafa, M. U. A., Daud, M. S., Senon, M. M., \& Ismail, M. N. B. (2013). The career tendency as entrepreneur among Bumiputra final year Agribusiness Diploma student, Kolej Profesional MARA College, Beranang. Post Graduate Seminar in Education.

Osman, M. H. M. (2007). Factors that affecting graduates and alumni of Universiti Teknologi Malaysia to venture into entrepreneurship. Management and Human Resource, Universiti Teknologi Malaysia.

Pihie, Z., A., L., \& Hassan, H. (2009). Choice of self-employment intentions among secondary school students. Journal of International Social Research, 2(9), 539-549. 
INTERNATIONAL JOURNAL OF ACADEMIC RESEARCH IN BUSINESS AND SOCIAL SCIENCES

Vol. 10, No. 15, Youth and Community Wellbeing: Issues, Challenges and Opportunities for Empowerment V1. 2020, E-ISSN: 2222-6990 @ 2020 HRMARS

Reardon, R. C., Lenz, J. G., Sampson, J. P., Jr., \& Peterson, G. W. (2012). Career development and planning: A comprehensive approach (4th ed.). Dubuque, IA: Kendall Hunt.

Sampson, J. P., McClain, M.-C., Musch, E., \& Reardon, R. C. (2013). Variables affecting readiness to benefit from career interventions. The Career Development Quarterly, 61(2),98-109. doi:10.1002/j.2161-0045.2013.00040.x

Sidiropoulou-Dimakakou, D., Mylonas, K., Argyropoulou, K., \& Tampouri, S. (2012). Career decision making difficulties, dysfunctional thinking and generalized self-efficacy of university students in Greece. World Journal of Education, 2(1), 117-130. doi:10.5430/wje.v2n1p117.

Salim, S. (1996). Counselling \& Guidance. Kuala Lumpur, Malaysia: Utusan Publications \& Distributors.

Thrift, M. M., Ulloa-heath, J., Reardon, R. C., \& Peterson, G. W. (2012). Career interventions and the career thoughts of Pacific Island college students. Journal of Counseling Development, 90, 169-177.

Tunggak, B., Salamon, H., \& Abu, B. (2011). Training and continues education necessity towards the development of Muslim entrepreneur based on Islamic values in Malaysia. Universiti Teknologi Malaysia. Jurnal Teknologi (Sains Sosial), 121-144.

UNIRAZAK. (2015). Entrepreneurship trends in Malaysia: A National Five Year (2009-2013) Longitudinal Study Using GEM Methodology. Kuala Lumpur: Universiti Tun Abdul Razak.

Yusof, Y. (2012). Entrepreneurship tendency among Bandar Penawar and Pasir Gudang Community College students. Master Thesis Dissertation, Universiti Teknologi Malaysia.

Yusof, N., Jamaluddin, Z., \& Lazim, N. M. (2013). The perception of undergraduates' student towards the marketability of graduate and competition in the job market, Jurnal Personalia Pelajar, 16, 77-92. 